\section{OPEN ACCESS}

Edited by:

Ferran Jori,

Centre de Coopération Internationale en Recherche Agronomique pour le Développement (CIRAD), France

Reviewed by:

Dadin Prando Moore,

Consejo Nacional de Investigaciones

Científicas y Técnicas

(CONICET), Argentina

Ignacio Ferre,

Complutense University of

Madrid, Spain

*Correspondence:

Luiz Daniel de Barros

daniel_vetuel@hotmail.com

João Luis Garcia

joaoluisgarcia10@gmail.com

Specialty section:

This article was submitted to Veterinary Epidemiology and

Economics,

a section of the journal

Frontiers in Veterinary Science

Received: 30 April 2020

Accepted: 22 June 2020

Published: 11 August 2020

Citation:

de Barros LD, Garcia JL, Bresciani KDS, Cardim ST, Storte VS and Headley SA (2020) A Review of

Toxoplasmosis and Neosporosis in Water Buffalo (Bubalus bubalis)

Front. Vet. Sci. 7:455. doi: 10.3389/fvets.2020.00455

\title{
A Review of Toxoplasmosis and Neosporosis in Water Buffalo (Bubalus bubalis)
}

\begin{abstract}
Luiz Daniel de Barros ${ }^{1 *}$, João Luis Garcia ${ }^{1 *}$, Katia Denise Saraiva Bresciani ${ }^{2}$, Sérgio Tosi Cardim ${ }^{3}$, Victor Sesnik Storte ${ }^{3}$ and Selwyn Arlington Headley ${ }^{4}$
\end{abstract}

\begin{abstract}
'Laboratory of Animal Protozoology, Department of Preventive Veterinary Medicine, Universidade Estadual de Londrina, Londrina, Brazil, ${ }^{2}$ School of Veterinary Medicine Araçatuba, Universidade Estadual Paulista, Araçatuba, Brazil, ${ }^{3}$ Department of Veterinary Medicine, Universidade Norte Do Paraná, Arapongas, Brazil, ${ }^{4}$ Laboratory of Animal Pathology, Department of Preventive Veterinary Medicine, Universidade Estadual de Londrina, Londrina, Brazil
\end{abstract}

Toxoplasmosis and neosporosis are diseases with worldwide distribution that are associated with reproductive problems in livestock and responsible for economic losses. This review presents an overview of the current knowledge relative to these diseases in water buffalo (Bubalus bubalis). In general, buffalo are considered resistant to clinical toxoplasmosis because there are studies only reporting serological evidence of natural infection in these animals. Studies have described age, poor hygienic status of the farm, and presence of cats as risk factors for the development of Toxoplasma gondii infection in buffalo. It must be highlighted that buffalo meat, which does not receive adequate freezing treatment, could be a potential source for toxoplasmic human infection as well as the importance of raw buffalo milk in the transmission of toxoplasmosis to human beings. Neospora caninum is considered one of the major causes of abortion and responsible for huge economic losses in cattle. Vertical transmission is the main route to infect calves, and is responsible for maintaining the parasite within a herd. In buffalo, vertical transmission is also described; moreover, although there are indications that $N$. caninum may be associated with abortion in dairy buffalo, the reproductive importance of neosporosis is apparently lower in buffalo relative to cattle. Most studies have identified a higher time of exposition to $N$. caninum oocysts relative to age. The household system was also described as a risk factor for infection, possibly due to persistent contact between the home-raised buffalo and canids. The fetal immune competence of buffalo is similar to bovine, and buffalo fetus are highly susceptible to infection during the first trimester of pregnancy, indicating that $N$. caninum may be an abortigenic agent in buffaloes. Alternatively, it is interesting to note there is evidence that the inflammatory response in pregnant buffalo infected with $N$. caninum is mild enough to avoid abortion in most cases. It is proposed that the possible transmission of toxoplasmosis through unprocessed milk and buffalo meat may occur, which is important in terms of public health. Additionally, there is strong evidence to suggest that $N$. caninum may be associated with abortion in buffalo.

Keywords: Toxoplasma gondii, Neospora caninum, water buffalo, Bubalus bubalis, epidemiology 


\section{INTRODUCTION}

The domestic water buffalo (Bubalus bubalis) is originated from the domestication of the Indian wild buffalo (Bubalus arnee), which occurred $\sim 5,000$ years ago (1). Currently, there is an estimated population of 202 million heads, predominantly in Asia (97\%), followed by Africa (1.7\%) and South America (1\%) (2). The buffalo population has been increasing in the last 10 years, probably because these animals are more resistant to infectious diseases and have better converting rates of poor-quality forage into milk and meat than cattle (1-3).

Toxoplasmosis and neosporosis are diseases caused by protozoan Toxoplasma gondii and Neospora caninum, respectively. These parasites have worldwide distribution and are associated with reproductive problems in livestock and responsible for economic losses (4-6). Buffalo appear to have fewer clinical problems with $T$. gondii, and only serological reports have published; however, it is a zoonotic disease, and attention should be taken relative to the drinking of buffalo milk. Regarding neosporosis in buffalo, although there are several serological studies, the importance of this disease as an abortive agent remains uncertain (7). Therefore, this review presents an overview of the current knowledge of toxoplasmosis and neosporosis in buffalo.

\section{TOXOPLASMOSIS}

\section{Introduction}

Toxoplasma gondii is a protozoan parasite that is able to infect different animal species, including humans, and has a worldwide distribution (5). Felids are the definitive hosts, being able to shed unsporulated oocysts through feces, which, after sporulation in the environment, can infect many animals, and humans (5). Mammals and birds are the intermediate hosts due to the development of tissue cysts and can be infected by the ingestion of food and water contaminated with sporulated oocysts or by the ingestion of raw or undercooked meat contaminated with tissue cysts (8). Moreover, vertical transmission is an important form of parasitic infection in humans and domestic animals, such as pigs and sheep (9-11). The infection in immunocompetent humans is usually asymptomatic; however, recent studies have reported clinical cases associated with outbreaks $(12,13)$. In livestock, especially in goats and sheep, toxoplasmosis is responsible for economic losses, mainly due to reproductive disorders, which include abortion, stillbirth, and birth of weak animals (4). The economic impact of toxoplasmosis includes the costs associated with treatment and the reduction in the expected output production (14). In general, buffaloes are considered resistant to the clinical disease, and thus, there are studies only reporting serological evidence of natural infection in these animals.

\section{Epidemiology}

Because buffalo meat and milk are used for human consumption, concern relative to the sanitary condition in buffalo herds has increased over the last 10 years (15). Several serological evaluations published worldwide have estimated that the serological status of the contact between buffaloes and $T$. gondii attained prevalence rates ranging from 0 to $87.79 \%$. Table 1 shows the serological studies for T. gondii in buffalo worldwide, and Figure 1 summarizes the prevalence rates. Different serological techniques, mainly targeting IgG antibodies, for the diagnosis of toxoplasmosis in buffalo were used; these include the indirect fluorescent antibody test (IFAT), enzymelinked immunosorbent assay (ELISA), modified agglutination test (MAT), Sabin-Feldman dye test (SFDT), latex agglutination test (LAT), and indirect hemagglutination (IHA). An ELISA assay was used to detect the IgM antibody for the diagnosing of acute infection in buffalo (39); however, the effectiveness of this assay is difficult to evaluate because this antibody is maintained only for few weeks after infection (48). The isolation of the parasite performed by mouse bioassay is the gold standard for the detection of T. gondii from tissue (5). A study evaluated the diaphragm from slaughter buffalo to isolate T. gondii; however, none of the infected mice were positive even those who were inoculated with tissue positive by PCR (46). A bioassay in cats was used to isolate $T$. gondii from the milk of buffalo, demonstrating that this model can be useful to isolate the parasite from different biological samples (49).

Many studies have evaluated risk factors associated with $T$. gondii infection in buffalo $(15,31,38,39,46,47,50)$. A significant difference was observed in the seroprevalence of buffalo from Mexico according to environmental conditions, where water buffalo raised in regions with annual rainfall between 1,266 and $1,650 \mathrm{~mm}$ had higher chances to be positive than those raised in regions with higher mean annual rainfall (50). Higher prevalence of IgM antibodies was verified in the monsoon season in Punjab, Pakistan, where the relative humidity, rainfall, and temperature are higher; these are ideal conditions for sporulation of oocysts in the environment (39). Changes in global climatic conditions have already been associated with a possible increase of $T$. gondii prevalence in humans from some regions of Europe (51).

Seroprevalence was considered to be comparatively more elevated in adult buffalo when compared with calves and juveniles (46). Other studies have also described age as a risk factor for the development of $T$. gondii infection in buffalo, where older animals are more seropositive than their younger counterparts $(15,31,39)$, probably due to the higher chance of older animals being exposed to the parasite as age increases. Most studies have not observed a significant association between the gender and seropositivity for toxoplasmosis $(31,39,46,47$, 50); however, a higher prevalence in male buffalo from Iran was observed, but all animals were under 2 years old, the age that was statically associated with infection (38). Conversely, a significant seroprevalence higher in female buffalo from Pakistan was verified with seropositivity being related to a lower immune response during the pregnancy and lactation periods (39).

When the type of rearing system was evaluated, a semiintensive and extensive rearing system showed higher seropositive animals compared to the intensive system, probably associated with the greater risk of animals ingesting oocysts present in pastures and becoming infected $(21,39)$. Differently, studies done with buffalo from Romania and Trinidad did not observe any association between rearing systems and the 
TABLE 1 | Seropositivity of Toxoplasma gondii in buffalo from different countries.

\begin{tabular}{|c|c|c|c|c|c|c|c|}
\hline \multicolumn{2}{|l|}{ Location } & Origin & Test & No. examined animals & $\%$ positive & Cutoff & References \\
\hline \multirow{3}{*}{ Africa } & Egypt & Farm & ELISA ${ }^{\mathrm{b}} / \mathrm{LAT}^{\mathrm{c}}$ & 55 & $74.5 / 20$ & n.a. ${ }^{i} /$ n. $^{j}{ }^{j}$ & (17) \\
\hline & Egypt & Slaughterhouse & MAT & 160 & 22.5 & 25 & (18) \\
\hline & Zimbabwe & Wild (Syncerus caffer) & MAT & 18 & 5.6 & 25 & (19) \\
\hline & Brazil & Farm & IFAT & 136 & 12.5 & 64 & (21) \\
\hline & Brazil & Farm & IFAT/ELISA & 4796 & $34.9 / 40.32$ & 40 & (22) \\
\hline & Brazil & Farm & IFAT & 500 & 38.5 & 64 & (23) \\
\hline & Brazil & Farm & IFAT/ELISA & 321 & $50.47 / 42.99$ & 64 & (24) \\
\hline & Brazil & Farm & LAT & 104 & 3.85 & 64 & (25) \\
\hline & Brazil & Farm & IFAT & 169 & 27.2 & 64 & (15) \\
\hline & Brazil & Farm & IFAT & 411 & 49.9 & 64 & (29) \\
\hline & Peru & Farm & $\mathrm{IHA} / \mathrm{e} F \mathrm{FT}$ & 70 & $35.7 / 17.1$ & $16 / 64$ & (30) \\
\hline & Trinidad & Farm & LAT & 333 & 7.8 & 64 & (31) \\
\hline \multirow[t]{7}{*}{ Asia } & China & Farm & $\| \mathrm{HA}$ & 83 & 0.0 & 64 & (32) \\
\hline & China & Farm & $\mid A T^{\dagger}$ & 40 & 0.0 & n.i. & (33) \\
\hline & China & Farm & $\mathrm{HA}$ & 427 & 7.5 & 64 & (34) \\
\hline & China & Farm & $\Perp \mathrm{HA}$ & 560 & 16.78 & 64 & (35) \\
\hline & India & Farm & ELISA & 103 & 2.91 & n.a. & (36) \\
\hline & Iran & Farm & IFAT & 385 & 8.8 & 16 & (37) \\
\hline & Iran & Slaughterhouse & MAT & 300 & 14.33 & 25 & (38) \\
\hline \multirow{3}{*}{ Europe } & Italy & Farm & ELISA & 124 & 13.7 & n.a. & (45) \\
\hline & Romania & Farm/Slaugtherhouse & MAT/ELISA & 197 & $9.64 / 6.6$ & 6 & (46) \\
\hline & Turkey & n.i. & SDFT ${ }^{h}$ & 131 & 87.79 & 16 & (47) \\
\hline
\end{tabular}

a Modified agglutination test.

${ }^{b}$ Enzyme-linked immunosorbent assay.

c Latex agglutination test.

a Indirect fluorescent antibody test.

e Indirect hemagglutination.

${ }^{f}$ Indirect agglutination test.

$g$ Direct agglutination test.

h Sabin-Feldman dye test.

${ }^{i}$ not applied.

j not informed.

occurrence of antibodies anti-T. gondii in buffalo $(31,46)$, maybe because of the climatic conditions in these countries.

Other risk factors associated with seroprevalence of toxoplasmosis in buffalo described in the literature are poor hygienic status of the farm and the presence of cats (39). Similar results were described in cattle, demonstrating the importance of cats in the epidemiology of $T$. gondii, because cats are usually common on farms and can shed millions of oocysts through feces, contaminating the environment $(14,52)$.

Reproductive disorders are usually associated with infection by $T$. gondii; however, there is only one study in water buffalo that analyzed this association, where two $(0.6 \%)$ out of 307 female 


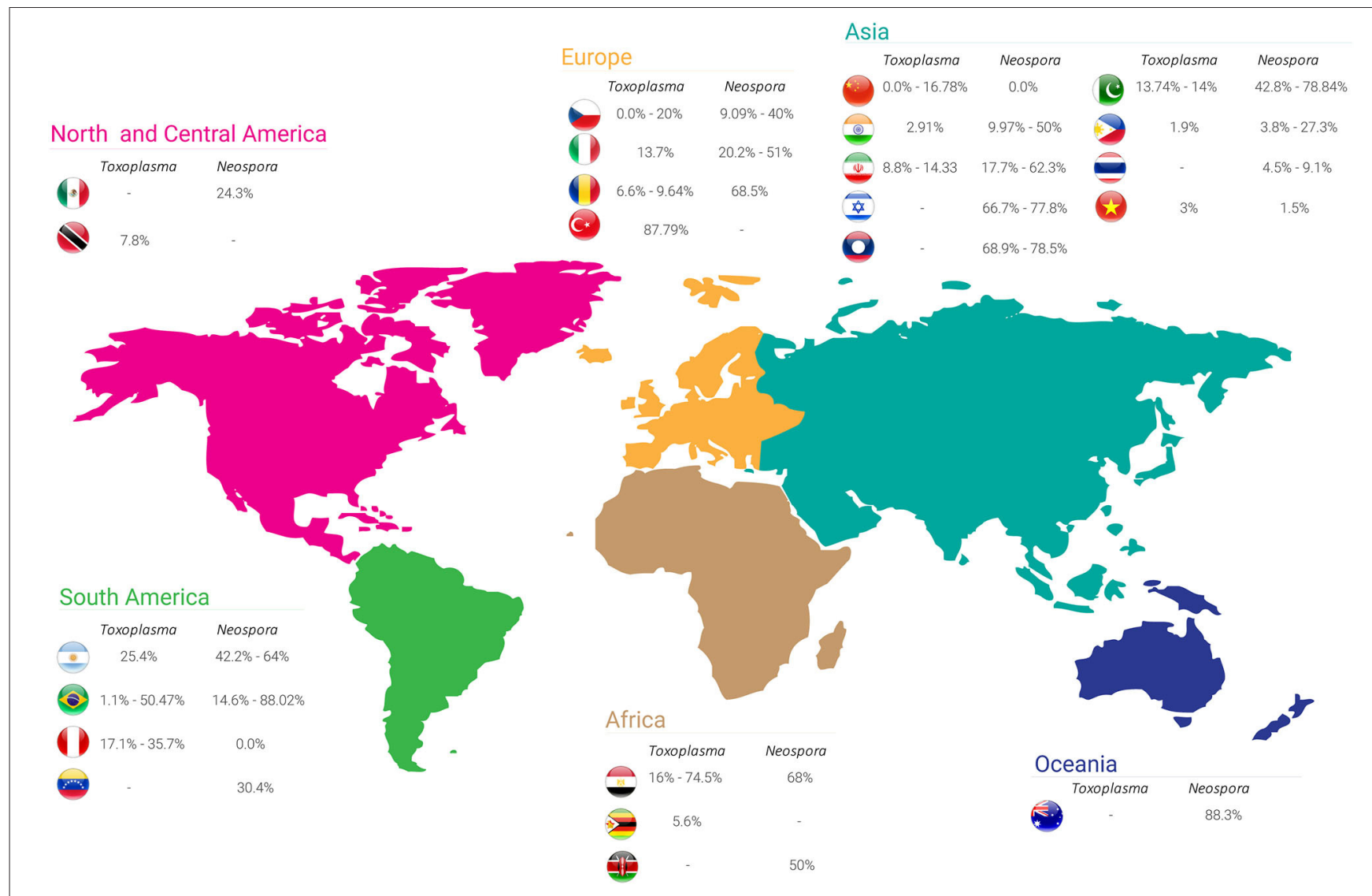

FIGURE 1 | Seroprevalence rates of Toxoplasma gondii and Neospora caninum in buffalo worldwide.

buffaloes from Mexico had a history of abortion and antibodies against $T$. gondii, resulting in a non-statistically significant association between toxoplasmosis and abortion in water buffalo (50). A recent study reported an association between $T$. gondii infection and a high number of days open (number of days from calving to conception) in water buffalo, and the authors hypothesized that the disease could result in embryonic death and resorption (45).

A study evaluated the presence of antibodies by MAT from 18 wild buffalo, including African buffalo (Syncerus caffer) from Zimbabwe, but only one animal was positive with titer of 25 (19). Five African buffalo (Syncerus caffer caffer), two Dwarf forest buffalo (Syncerus caffer nanus), and four water buffalo (Bubalus arnee) from a zoo in the Czech Republic were evaluated by IFAT, but only one African buffalo and one water buffalo were positive with titers of 80 and 640, respectively (43).

\section{Experimental Infections}

To the best of the author's knowledge, there is only one study that performed an experimental infection of T. gondii in buffalo, and it used eight calves inoculated with a T. gondii GT1 strain, five at $10^{5}$ and the other three with $5 \times 10^{5}$ oocysts (53). Five animals developed moderated pyrexia, anorexia, weakness, and dyspnea; one calf inoculated with the higher dose died 11 days post-inoculation (p.i.); and another inoculated with $10^{5}$ had to be euthanized 23 days p.i. because it was unable to eat and stand. Hematological changes were not observed, and the immunological response was first observed on day 21 p.i. by IHA at a cutoff of 64 . The antibodies persisted for 63 days and then declined below the cutoff. By mouse bioassay, T. gondii was isolated from the brain, lungs, liver, kidney, lymph nodes, and spleen from the calf that died of acute toxoplasmosis. Samples from the lymph nodes and retina were used to isolate the parasite from the calves that were euthanized at 23 and 32 days p.i. These authors reported that the pathological analysis revealed mild interstitial pneumonia in one calf without histopathological evidence of tissue cysts in any of the histological sections (53). The results derived from this study suggest that buffalo, like cattle, are considered resistant to clinical toxoplasmosis and probably do not play an important role in the epidemiology of T. gondii.

\section{Public Health Concerns}

Although different studies have described seropositivity in buffalo worldwide, the importance of buffalo meat for public health is currently unknown. In cattle, previous studies have not 
detected viable parasites in beef from meat stores (54); however, T. gondii should be considered an issue of public health in regions where buffalo meat is widely consumed (55). Fresh and imported frozen buffalo meat obtained from markets in Egypt were assessed for viable T. gondii by bioassay in cats, and the prevalence of tissue cysts in fresh meat was $15.4 \%$ although none of the frozen buffalo meat was considered positive (56). The process of freezing meat at $-20^{\circ} \mathrm{C}$ during importation probably inactivates the tissue cysts because freezing meat to temperature of $-12^{\circ} \mathrm{C}$ or below is efficient in destroying tissue cysts (5).

Toxoplasma gondii tissue cysts were isolated and detected by light microscopy of percoll dilutions in $15 \%$ of frozen buffalo meat that was illegally imported to Turkey from Iraq although all positive samples were confirmed by nested PCR using the B1 gene (57). Additionally, the meat was treated at $-18^{\circ} \mathrm{C}$ for 2 days, and tissue cysts were not identified after this process. It must be highlighted that, based on these results, the meat from this study did not receive adequate freezing treatment and could be a potential source for human infection.

Raw milk samples from 33 buffalo herds from Iran were collected from clinically healthy animals and without alterations in physical characteristics of milk for the detection of T. gondii (49). Out of 164 milk samples obtained from buffalo, $4.26 \%$ were considered positive at Vero cell culture, and 3.65\% and 3.04\% were positive by capture ELISA and B1 gene PCR, respectively. Additionally, positive samples by the cell culture were used for cat bioassay; animals were fed with $50 \mathrm{ml}$ of milk from buffalo for 3 days, and all challenged cats shed oocysts in the feces, demonstrating viable tachyzoites present in the milk (49). These results demonstrate the importance of raw milk in the transmission of toxoplasmosis to humans.

\section{NEOSPOROSIS}

\section{Introduction}

Neospora caninum is a protozoan parasite responsible for important diseases in dogs and cattle (58). In cattle, $N$. caninum is considered one of the major causes of abortion and responsible for severe economic losses (6). To date, only domestic dogs (Canis familiaris), Australian dingoes (Canis lupus dingo), coyotes (Canis latrans), and gray wolves (Canis lupus) are considered definitive hosts of the parasite (59-62). Although serological positivity against $N$. caninum was reported in several animal species, only a few are considered intermediate hosts, including some mammalian and bird species $(58,63)$. In humans, the presence of antibodies anti-N. caninum was described; however, the zoonotic potential remains unknown (64).

Vertical transmission is the main route of infection in calves and is responsible for maintaining the parasite within a herd $(65,66)$. In buffalo, vertical transmission was also described, but the importance of this form of transmission in the epidemiology of the disease in buffalo remains to be elucidated. Moreover, the reproductive importance of neosporosis in buffalo has to be clarified; however, this importance is apparently lower than in cattle (7).

\section{Epidemiology}

Table 2 shows the seroprevalence of neosporosis in buffalo worldwide with seropositivity ranging from 0 to $88.3 \%$ based on different serological assays. A summary of the seroprevalence rates of $N$. caninum in each country is shown in Figure 1. Although the seroprevalence in buffalo appears to be three times higher than in cattle, the association between N. caninum and reproductive disorders in buffalo seems not to be a common occurrence $(6,7)$.

Indirect ELISA and IFAT were the main techniques employed for the serological diagnosis of neosporosis in buffalo; however, a competitive-inhibition ELISA (cELISA) and a Neospora agglutination test (NAT) were also used. The NAT assay is similar to the MAT assay for the identification of toxoplasmosis; however, it uses $N$. caninum tachyzoites. Moreover, this technique can be done in different animal species because it does not require an anti-IgG conjugate and shows high sensitivity and specificity (99). An indirect ELISA was developed based on fragments of recombinant NcGRA7 for the diagnosis of $N$. caninum infection in buffalo (83). This new ELISA demonstrated $98.6 \%$ sensitivity and $86.5 \%$ specificity using buffalo sera, obtained a good correlation with a commercial ELISA, and seems to be a good tool for the serological screening of neosporosis in buffalo.

The presence of an immunodominant $17-18 \mathrm{kDa}$ antigen by Western blot was used to confirm the presence of antibodies anti$N$. caninum in buffalo from Israel (86). Western blot confirmed infection in $85.7 \%(12 / 14)$ of the positive samples by MAT and $84.6 \%(11 / 13)$ by IFAT, demonstrating high sensitivity for both techniques (86). Recently, a milk ELISA was evaluated as an alternative method to detect $N$. caninum antibodies in lactating buffalo (91). The milk iscom ELISA detected a comparatively reduced number of positive milk samples than competitive ELISA using serum samples; however, a moderate agreement between the techniques was observed, indicating that this milk ELISA could be used in lactating dairy herds with a high prevalence of neosporosis (91).

Bioassay in dogs, gerbils, and cell culture were done to isolate $N$. caninum from brain tissues of six buffalo seropositive by IFAT (cutoff $=100)(100)$. Four dogs shed oocysts through feces after being fed buffalo brain, the higher number of oocysts shed was 820,655 , and the higher duration of oocyst shedding was 26 days. These authors report that, by cell culture, N. caninum was isolated from the brains of two buffalo, and via bioassay in gerbils, the parasite was isolated from the brains of three buffalo. Additionally, the isolates, named NCBrBuf-1 to NCBrBuf4, were confirmed as N. caninum by PCR and DNA sequencing, targeting the Nc5 and ITS-1 region, and showed a low degree of genetic diversity between other N. caninum isolates (100). Collectively, these results demonstrate that buffalo are natural intermediate hosts for N. caninum; this study is the first report of isolation of the parasite in this species (100).

A recent study revealed a higher seroprevalence for $N$. caninum in adults relative to calves and young buffalo (97). This result is in accordance with previous studies (20, 68, 69, $82,87,95)$ and may be related to a comparative higher period 
TABLE 2 | Seropositivity of Neospora caninum in buffalo from different countries.

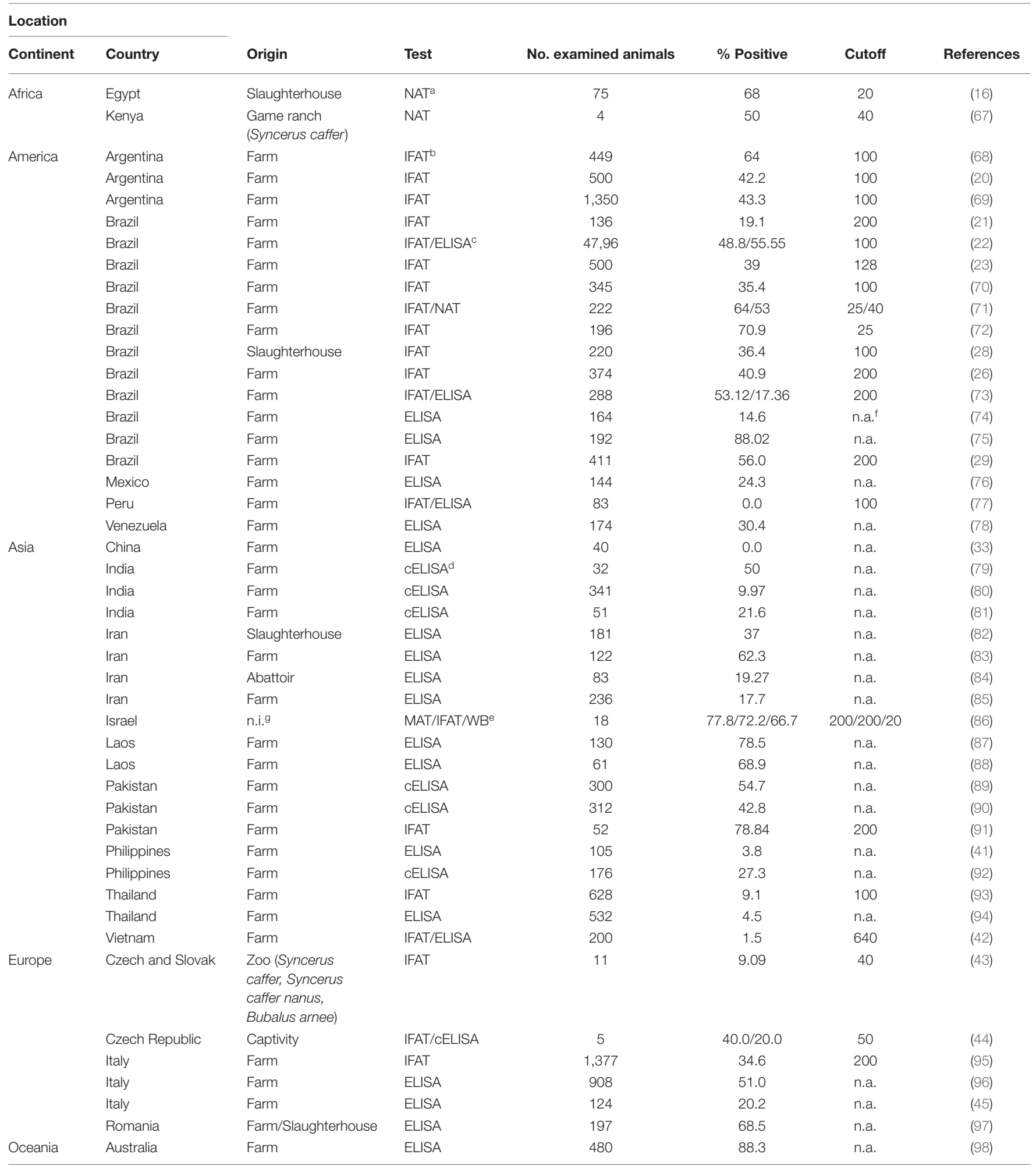

a Neospora caninum agglutination test.

${ }^{b}$ Indirect fluorescent antibody test.

c Enzyme-linked immunosorbent assay.

a Competitive-inhibition enzyme-linked immunosorbent assay (CELISA).

e Western blot.

${ }^{f}$ not applied.

$g$ not informed. 
of exposition to oocysts relative to age. A higher prevalence in older buffalo (more than 10 years old) was verified, suggesting that horizontal transmission occurs more commonly in buffalo than vertical transmission (93). Another study demonstrated an association between age and $N$. caninum seroprevalence by IFAT with higher prevalence in animals that were 6-11 years old; however, this association was not observed when these samples are analyzed by NAT (71). Alternatively, previous studies from Brazil (72), India (80), and Thailand (94) did not demonstrate statistical differences among age-related groups and neosporosis. When the gender of buffalo was compared, differences in infection by $N$. caninum were not identified between male and female in studies from Argentina (68), Thailand (93), and Pakistan $(89,90)$; however, serological surveys done in Iran (82) and Romania (97) showed statistical differences for gender with higher prevalence in female buffalo.

In female water buffalo from Brazil, the risk factors associated with neosporosis were grazing and animals derived from animal markets and/or reputable sellers (70), reinforcing the hypothesis of postanal transmission due to the ingestion of food or water contaminated with oocysts. By logistic regression analysis, the presence of pigs was considered as a risk factor for neosporosis in buffalo in Paraíba state, Brazil (21), although pigs do not play an important role in the epidemiology of $N$. caninum. The household system was also described as a risk factor by $N$. caninum, probably due to the persistent contact between home-raised buffalo and canids (97).

Contact with dogs was associated with infection in buffalo from Pakistan, suggesting the role of dogs in contaminating buffalo feed, resulting in horizontal transmission (89). In this same study, summer weather was also associated with seroprevalence of $N$. caninum in buffalo, and it was suggested to be related to the gestational phase of these animals because, during the Pakistan summer, most animals are in midgestation, which could result in changes in the immune system and parasite transmission (89).

Although reproductive disorders, such as abortion, appear to be less common in buffalo relative to cattle, the prevalence of $N$. caninum antibodies was significantly higher in dairy buffalo that had a history of abortion than those without any abortive history, indicating that this agent may be associated with abortion in dairy buffalo (89). It was reported that, in 167 buffalo seropositive for N. caninum, 13.2\% (22/167) were co-infected with Brucella abortus, indicating a higher abortion risk in these animals than if infected with only one of these pathogens (90). Similarly, $N$. caninum infection was associated with abortion and retained fetal membranes, indicating that neosporosis can be related to reproductive disorders in water buffalo (45).

Neospora-like cysts were observed in the brain of the fetuses of two buffalo by histological analysis on a farm in Italy that had a history of abortion and death of buffalo calves with neurological manifestations (95); however, additional confirmation of the identity of the intralesional cysts by other diagnostic methods, such as immunohistochemistry on in situ hybridization, was not done to confirm these tissue cysts as $N$. caninum (95). It was demonstrated that, in 17 calves born from seropositive dams, antibodies anti-N. caninum persisted for 12 months, suggesting neonatal transmission of the parasite in buffalo, probably by the transplacental route (101). However, the first evidence of congenital transmission of $N$. caninum in buffalo was suggested in a 3-month-old fetus that was negative at IFAT and brain tissue positive by a nested PCR assay that targeted the ITS1 and Nc5 regions (102). These conflicting results could be due to the immunocompetency of the fetus (102).

DNA from $N$. caninum was detected by qPCR in the fetus of one water buffalo from a fetus from a dam that was 23 years old, during which abortion occurred between 180 and 210 days of gestation (103); however, the authors concluded that they could not have confirmed if neosporosis was the only cause of abortion because other abortive agents could be present. Consequently, they suggest that $N$. caninum could be responsible for reproductive failure in water buffalo. $N$. caninum DNA was identified by $18 \mathrm{~S}$ PCR assay in the brains and hearts of three buffalo fetuses that suffered spontaneous abortion between the fourth and 6 months of gestation (96). Additionally, these fetal tissues were considered negative for the major pathogens responsible for reproductive failures in buffalo, including Brucella spp., Salmonella spp., Chlamydophila spp., Listeria spp., Campylobacter spp., Coxiella burnetti, Leptospira spp., Toxoplasma gondii, Bovine and Bubaline Herpesvirus (BoHV1 and BuHV1), and bovine viral diarrhea virus (BVDV), indicating $N$. caninum as an important abortive agent (96). In a recently published study, a Neospora-associated abortion was reported for the first time in buffalo from India, where tissues from two fetuses were positive by immunohistochemistry (81).

The presence of the parasite DNA was detected by nested PCR assay only at the diaphragm (heart and mesenteric lymph node were also evaluated) from six animals $(8.1 \%, 6 / 74)$ of different ages; three of these animals also were negative by serological assays (97). These results demonstrate that the diaphragm may be an adequate tissue for the detection of $N$. caninum in buffalo and that serologically negative animals can also have the parasite in their tissues.

Recently, it was demonstrated that buffalo with higher titers of antibodies against $N$. caninum also contained parasite DNA in the serum samples, being the first report to confirm N. caninum DNA in serum samples of buffalo and indicating that parasitemia occurs simultaneously with antibody production (84).

\section{Experimental Infections}

The first experimental study with $N$. caninum in buffalo was performed in 2005 when the authors inoculated six buffalo with $5 \times 10^{6}$ tachyzoites of Illinois strain by subcutaneous route (101). All animals were positive between 7 and 11 days p.i. by IFAT with a cutoff of 25 , and titers peaked at 3 weeks p.i. and remained elevated until 7 weeks p.i., after which the peak started to decrease (101).

Intravenous inoculation of $10^{8}$ tachyzoites of the NC-1 strain was performed in an experimental study involving 10 female water buffalo at $70(n=3)$ or $90(n=7)$ days of pregnancy (104). Although all dams developed specific antibodies with titers ranging from 3,200 to 51,200 , none of these showed clinical signs or aborted; however, one non-viable fetus was observed from a female inoculated at 70 days of gestation and slaughtered 
at 28 days p.i. (104). Specific antibodies against $N$. caninum (cutoff $=10$ ) were detected in only two fetuses; both dams were inoculated at 90 days of gestation and slaughtered at 72 days p.i. Moreover, N. caninum DNA was detected by nPCR in the placenta and fetuses of all inoculated animals (104). These results indicate that fetal immune competence of buffalo is similar to that of cattle at $\sim 110$ days of gestation, and fetuses of buffalo are highly susceptible to infection during the first trimester of pregnancy, indicating that $N$. caninum should be considered as an abortigenic agent in water buffalo.

An experimental infection was done to evaluate the outcome of infection with different strains of $N$. caninum in six pregnant buffalo at the 70th day of gestation with $5 \times 10^{8}$ tachyzoites by intravenous route (105). Three pregnant buffalo with the NC1 strain and the others with the NC-Bahia, a Brazilian strain isolated from the brain of a naturally infected dog. Additionally, all the females developed antibodies detected by ELISA and IFAT (cutoff $=50$ ), but none of the fetuses were considered seropositive (cutoff $=25$ ). Moreover, fetal death occurred in all females infected with the NC-1 strain but not in dams inoculated with the NC-Bahia strain. Furthermore, a semi-nested PCR detected $N$. caninum DNA in maternal and fetal tissues, indicating transplacental transmission in all animals, but the NC-Bahia seems to be less virulent for pregnant buffalo (105).

\section{Pathogenesis}

Neospora caninum is recognized as one of the major causes of reproductive failures in cattle; however, little is known about the pathogenesis of the disease in buffalo. So far, natural abortion in buffalo by neosporosis was only reported in one study (96), and all knowledge relative to the pathogenesis is based on experimental observations.

Non-suppurative encephalitis and myocarditis were observed in aborted fetuses, and few N. caninum-like cysts were identified in histologic sections of the brain, but none of the molecular techniques were used, compromising the diagnoses as $N$. caninum (95).

Challenged pregnant female buffalo with $N$. caninum tachyzoites developed non-suppurative placentitis as the more frequent histopathologic finding, being observed in 9 out of 10 specimens (104). Additionally, meningoencephalitis, characterized by gliosis and non-suppurative inflammatory infiltration at the pia mater with multiple necrotizing foci at the central nervous system, were observed in fetuses derived these female buffalo. Moreover, in other fetal tissues, including the lungs, heart, kidneys, striated muscle, and liver, multiple foci of mononuclear inflammatory cells were observed in almost all samples analyzed, and immunohistochemistry identified intralesional tachyzoites in two fetuses that were associated with focal necrosis and gliosis in the central nervous system in one of these (104).

Non-suppurative inflammation in placentomes and fetal tissue was also observed after infection of nine pregnant buffalo in early gestation with the NC-1 strain of N. caninum (106). Moreover, a mononuclear inflammatory infiltrate was identified surrounding the necrotic foci at the caruncle or within necrotic fetal villi in the placentome of all dams challenged at 70 days of gestation with $10^{8}$ tachyzoites of the NC-1 strain of N. caninum and culled at 28 days p.i. with higher scores in dams carrying nonviable fetuses. These authors suggested that the inflammatory response in pregnant buffalo infected with $N$. caninum was mild enough to avoid abortion in most of the cases (106).

Lymphocytic infiltration was the main lesion observed in placental and fetal tissues after pregnant buffalo were inoculated with two strains of $N$ caninum (105). Hemorrhagic hepatitis and nephritis were observed in the fetuses, and necrosis at the placenta and fetal brain were also observed. These authors indicate that the fetuses from the dam inoculated with the NCBahia strain contained fewer lesions with comparatively less severity when compared with fetuses inoculated with $\mathrm{NC}-1$ strain, indicating that the NC-Bahia strain is more pathogenic than the NC-1 strain of N. caninum (105).

Mild satellitosis of the brain and perivascular macrophage at the heart were observed in two pregnant buffalo inoculated with NC-1 tachyzoites (75). Additionally, periportal non-suppurative hepatitis with centrilobular infiltration of macrophages and perivascular mononuclear cell infiltration at the kidney was also observed in these females. Moreover, brain tissues from fetuses from these pregnant buffalo presented multifocal necrosis and gliosis associated with infection by N. caninum, and the fetuses revealed non-suppurative myocarditis and pericarditis with macrophage infiltration, myositis, lymphocytic and macrophagic portal hepatitis, and a non-suppurative nephritis with perivascular and periglomerular lymphocytic and macrophage infiltration. Furthermore, the kidney of one of the fetuses had hemorrhage in the renal pelvis, and lung tissue from other fetuses showed peribronchiolar lymphocytic and macrophage infiltration with multifocal hemorrhage (75).

\section{CONCLUSIONS}

The buffalo industry is growing worldwide, and the review of the literature indicates that the possible transmission of toxoplasmosis through either unprocessed milk or buffalo meat may occur. Furthermore, considering the high T. gondii seroprevalence observed in these animals, we could consider that the public health risk incurred by persons exposed to infected animals is probably higher than previously assumed. We summarized all seroprevalence studies of $N$. caninum in buffalo, which showed a high prevalence worldwide Additionally, there is strong evidence to suggest that $N$. caninum may be associated with abortion in buffalo. Finally, the present review will contribute to lightening future studies in this field.

\section{AUTHOR CONTRIBUTIONS}

LB, JG, KB, SC, VS, and SH contributed to conception, design, drafting, and critical revision of the manuscript. All authors contributed to the article and approved the submitted version.

\section{ACKNOWLEDGMENTS}

JG, KB, and $\mathrm{SH}$ are recipients of $\mathrm{CNPq}$ fellowships. 


\section{REFERENCES}

1. Borghese A. Buffalo Production and Research. Reu Techni. Rome: Food and Agriculture Organization of the United Nations. (2005).

2. Zhang Y, Colli L, Barker JSF. Asian water buffalo: domestication, history and genetics. Anim Genet. (2020) 51:177-91. doi: 10.1111/age.12911

3. Michelizzi VN, Dodson MV, Pan Z, Amaral MEJ, Michal JJ, McLean DJ, et al. Water buffalo genome science comes of age. Int J Biol Sci. (2010) 6:333-49. doi: 10.7150/ijbs.6.333

4. Dubey JP. Toxoplasmosis in sheep-The last 20 years. Vet Parasitol. (2009) 163:1-14. doi: 10.1016/j.vetpar.2009.02.026

5. Dubey JP. Toxoplasmosis of Animals and Humans. 2nd ed. Boca Raton, FL: CRC Press. (2010)

6. Reichel MP, Alejandra Ayanegui-Alcérreca M, Gondim LFP, Ellis JT. What is the global economic impact of Neospora caninum in cattle - the billion dollar question. Int J Parasitol. (2013) 43:133-42. doi: 10.1016/j.ijpara.2012.10.022

7. Reichel MP, Mcallister MM, Nasir A, Moore DP. A review of Neospora caninum in water buffalo (Bubalus bubalis). Vet Parasitol. (2015) 212:759. doi: 10.1016/j.vetpar.2015.08.008

8. Dubey JP, Jones JL. Toxoplasma gondii infection in humans and animals in the United States. Int $J$ Parasitol. (2008) 38:1257-78. doi: 10.1016/j.ijpara.2008.03.007

9. Remington JS, Klein JO, Baker CJ, Wilson CB. Infectious Diseases of the Fetus and Newborn Infant. Philadelphia, PA: WB Saunders (2006). doi: 10.1016/B0-7216-0537-0/X5001-4

10. Bresciani KDS, Costa AJC. Congenital Toxoplasmosis in Human and Domestic Animals. Sharjah: Bentham Science Publishers. (2018).

11. Garcia JL. Congenital toxoplasmosis in pigs. In: Congenital Toxoplasmosis in Human and Domestic Animals. Sharjah: Bentham Science Publishers (2018). p. 82-95.

12. Minuzzi CE, Portella LP, Bräunig P, Sangioni LA, Ludwig A, Ramos LS, et al. Isolation and molecular characterization of Toxoplasma gondii from placental tissues of pregnant women who received toxoplasmosis treatment during an outbreak in southern Brazil. PLoS ONE. (2020) 15:e0228442 doi: 10.1371 /journal.pone. 0228442

13. Pinto-Ferreira F, Mitsuka-Breganó R, Monica TC, Martins FDC, Matos RLN de, Mareze $M$, et al. Investigation and environmental analysis of samples from outbreak of toxoplasmosis at research institution in londrina, paraná, Brazil, 2016. Rev Bras Parasitol Veterinária. (2019) 28:518521. doi: 10.1590/s1984-29612019044

14. Stelzer S, Basso W, Benavides Silván J, Ortega-Mora LM, Maksimov P, Gethmann J, et al. Toxoplasma gondii infection and toxoplasmosis in farm animals: risk factors and economic impact. Food Waterborne Parasitol. (2019) 15:e00037. doi: 10.1016/j.fawpar.2019.e00037

15. Santos LM, Damé M, Cademartori B, da Cunha Filho NA, Farias NA, Ruas JL. Occurrence of antibodies to Toxoplasma gondii in water buffaloes and meat cattle in rio grande do sul state, southern Brazil. Acta Parasitol. (2013) 58:334-6. doi: 10.2478/s11686-013-0148-4

16. Dubey JP, Romand S, Hilali M, Kwok OCH, Thulliez P. Seroprevalence of antibodies to neospora caninum and Toxoplasma gondii in water buffaloes (Bubalus bubalis) from egypt. Int J Parasitol. (1998) 28:5279. doi: 10.1016/S0020-7519(97)00190-2

17. Kuraa HM, Malek SS. Seroprevalence of Toxoplasma gondii in ruminants by using latex agglutination test (LAT) and enzyme-linked immunosorbent assay (ELISA) in assiut governorate. Trop Biomed. (2016) 33:711-25.

18. Shaapan RM, Hassanam MA, Khahl FAM. Modified agglutination test for serologic survey of Toxoplasma gondii infection in goats and water buffaloes in Egypt. Res J Parasitol. (2010) 5:13-7. doi: 10.3923/jp.2010.13.17

19. Hove T, Dubey JP. Prevalence of Toxoplasma gondii antibodies in sera of domestic pigs and some wild game species from Zimbabwe. J Parasitol. (1999) 85:372-3. doi: 10.2307/3285650

20. Konrad JL, Campero LM, Caspe GS, Brihuega B, Draghi G, Moore DP, et al. Detection of antibodies against Brucella abortus, Leptospira spp., and apicomplexa protozoa in water buffaloes in the Northeast of Argentina. Trop Anim Health Prod. (2013) 45:1751-6. doi: 10.1007/s11250-013-0427-y

21. Brasil AW de L, Parentoni RN, Feitosa TF, Bezerra C de S, Vilela VLR, Pena HF de J, Azevedo SS de. Risk factors for Toxoplasma gondii and Neospora caninum seropositivity in buffaloes in Paraiba State, Brazil. Rev Bras Parasitol Veter. (2015) 24:459-63. doi: 10.1590/s1984-29612015066

22. da Silva JB, Dos Santos PN, De Santana Castro GN, Da Fonseca $\mathrm{AH}$, Barbosa JD. Prevalence survey of selected bovine pathogens in water buffaloes in the North Region of Brazil. J Parasitol Res. (2014) 2014:603484. doi: 10.1155/2014/603484

23. da Silva JB, Nicolino RR, Fagundes GM, dos Anjos Bomjardim H, dos Santos Belo Reis A, da Silva Lima DH, et al. Serological survey of Neospora caninum and Toxoplasma gondii in cattle (Bos indicus) and water buffaloes (Bubalus bubalis) in ten provinces of Brazil. Comp Immunol Microbiol Infect Dis. (2017) 52:30-5. doi: 10.1016/j.cimid.2017.05.005

24. De Oliveira JP, Casseb ADR, Ramos ADS, Filho STR, Nogueira HL, Pinho $\mathrm{RO}$, et al. Risk factors associated with the epidemiology of Toxoplasma gondii in cattle and buffaloes in the state of Pará, Brazil. Semin Agrar. (2018) 39:2029-38. doi: 10.5433/1679-0359.2018v39n5p2029

25. Pita Gondim LF, Barbosa H V., Ribeiro Filho CHA, Saeki H. Serological survey of antibodies to Toxoplasma gondii in goats, sheep, cattle and water buffaloes in Bahia State, Brazil. Vet Parasitol. (1999) 82:2736. doi: 10.1016/S0304-4017(99)00033-3

26. Silva SP, Mota RA, Faria EB, Fernandes EFTS, Neto OLS, Albuquerque PPF, et al. Anticorpos IgG anti-Neospora caninum e Toxoplasma gondii em búfalas (Bubalus bubalis) criadas no estado do pará. Pesqui Vet Bras. (2010) 30:443-6.doi: 10.1590/\$0100-736X2010000500012

27. da Silva JB, da Fonseca AH, de Andrade SJT, Silva AGM, Oliveira CMC, Barbosa JD. Prevalência de anticorpos anti-Toxoplasma gondii em búfalos (Bubalus bubalis) no estado do pará. Pesqui Veterinária Bras. (2013) 33:5815. doi: 10.1590/S0100-736X2013000500005

28. Portella LP, Cadore GC, Lima M de, Sangioni LA, Fischer G, Vogel FSF. Antibodies against Neospora caninum, Sarcocystis spp. and Toxoplasma gondii detected in buffaloes from rio Grande do Sul, Brazil. Pesqui Vet Bras. (2016) 36:947-50 doi: 10.1590/S0100-736X2016001000005

29. de Souza LM, do Nascimento AA, Furuta PI, Basso LMS, da Silveira DM, da Costa AJ. Detecção de anticorpos contra Neospora caninum e Toxoplasma gondii em soros de bubalinos (Bubalus bubalis) no Estado de São Paulo, Brasil. Semin Ciências Agrárias. (2001) 22:3948. doi: 10.5433/1679-0359.2001v22n1p39

30. Esteves V K, Chávez V A, Casas A E, Lí E O. Determinación de anticuerpos contra Toxoplasma gondii en búfalos de agua (Bubalus bubalis) en el distrito de Jenaro Herrera, Loreto, Perú. Rev Investig Vet del Peru. (2013) 24:3905.doi: 10.15381/rivep.v24i3.2589

31. Persad A, Charles R, Adesiyun AA. Frequency of toxoplasmosis in water buffalo (Bubalus bubalis) in Trinidad. Vet Med Int. (2011) 2011:705358. doi: 10.4061/2011/705358

32. Shen L, Zhichung L, Biaucheng Z, Huayuan Y. Prevalence of Toxoplasma gondii infection in man and animals in guangdong, people's republic of China. Vet Parasitol. (1990) 34:357-60. doi: 10.1016/0304-4017(90) 90082-M

33. Yu J, Xia Z, Liu Q, Liu J, Ding J, Zhang W. Seroepidemiology of Neospora caninum and Toxoplasma gondii in cattle and water buffaloes (Bubalus bubalis) in the people's republic of China. Vet Parasitol. (2007) 143:7985. doi: 10.1016/j.vetpar.2006.07.031

34. Zou F, Yu X, Yang Y, Hu S, Chang H, Yang J, et al. Seroprevalence and risk factors of Toxoplasma gondii infection in buffaloes, sheep and goats in Yunnan province, Southwestern China. Iran J Parasitol. (2015) 10:648651. PIMID:26811733

35. Luo H, Li K, Zhang H, Gan P, Shahzad M, Wu X, et al. Seroprevalence of Toxoplasma gondii infection in zoo and domestic animals in jiangxi province, China. Parasite. (2017) 24:7. doi: 10.1051/parasite/2017007

36. Sharma S, Sandhu KS, Bal MS, Kumar H, Verma S, Dubey JP. Serological survey of antibodies to Toxoplasma gondii in sheep, cattle, and buffaloes in Punjab, India. J Parasitol. (2008) 94:1174-5. doi: 10.1645/ge-1556.1

37. Navidpour S, Hoghooghi-Rad N. Seroprevalence of anti-Toxoplasma gondii antibodies in buffaloes in Khoozestan province, Iran. Vet Parasitol. (1998) 77:191-4. doi: 10.1016/S0304-4017(97)00148-9

38. Hamidinejat H, Ghorbanpour M, Nabavi L, Haji Hajikolaie MR, Razi Jalali MH. Seroprevalence of Toxoplasma gondii in water buffaloes (Bubalus bubalis) in South-West of Iran. Trop Biomed. (2010) 27:275-79. 
39. Ahmad N, Qayyum M. Seroprevalence and risk factors for toxoplasmosis in large ruminants in northern Punjab, Pakistan. J Infect Dev Ctries. (2014) 8:1022-8. doi: 10.3855/jidc.4405

40. Anees A, Maqbool A, Khan UJ, Yasmin G, Zahra F. Seroprevalence of antibodies to Toxoplasma gondii in butchers and buffaloes at Lahore, Pakistan. Pak J Zool. (2014) 46:1479-82.

41. Konnai S, Mingala CN, Sato M, Abes NS, Venturina FA, Gutierrez CA, et al. A survey of abortifacient infectious agents in livestock in Luzon, the Philippines, with emphasis on the situation in a cattle herd with abortion problems. Acta Trop. (2008) 105:269-73. doi: 10.1016/j.actatropica.2007.12.004

42. Huong LTT, Ljungström BL, Uggla A, Björkman C. Prevalence of antibodies to Neospora caninum and Toxoplasma gondii in cattle and water buffaloes in southern Vietnam. Vet Parasitol. (1998) 75:537. doi: 10.1016/S0304-4017(97)00178-7

43. Sedlák K, Bártová E. Seroprevalences of antibodies to Neospora caninum and Toxoplasma gondii in zoo animals. Vet Parasitol. (2006) 136:22331. doi: 10.1016/j.vetpar.2005.11.021

44. Bártová E, Kobédová K, Lamka J, Kotrba R, Vodička R, Sedlák K. Seroprevalence of Neospora caninum and Toxoplasma gondii in exotic ruminants and camelids in the Czech Republic. Parasitol Res. (2017) 116:1925-9. doi: 10.1007/s00436-017-5470-6

45. Ciuca L, Borriello G, Bosco A, D'andrea L, Cringoli G, Ciaramella P, et al. Seroprevalence and clinical outcomes of neospora caninum, Toxoplasma gondii and besnoitia besnoiti infections in water buffaloes (Bubalus bubalis). Animals. (2020) 10:532. doi: 10.3390/ani10030532

46. Bărburaş D, Györke A, Blaga R, Bărburaş R, Kalmár Z, Vişan S, et al. Toxoplasma gondii in water buffaloes (Bubalus bubalis) from romania: what is the importance for public health? Parasitol Res. (2019) 118:2695703 doi: 10.1007/s00436-019-06396-6

47. Beyhan YE, Babür C, Yilmaz O. Investigation of anti-Toxoplasma gondii antibodies in water buffaloes (Bubalus bubalis) in samsun and afyon provinces. Turkiye Parazitol Derg. (2014) 38:220-22. doi: 10.5152/tpd.2014.3592

48. Lindsay DS, Dubey JP. Neosporosis, toxoplasmosis, and sarcocystosis in ruminants: an update. Vet Clin North Am Food Anim Pract. (2020) 36:20522. doi: 10.1016/j.cvfa.2019.11.004

49. Dehkordi FS, Haghighi Borujeni MR, Rahimi E, Abdizadeh R. Detection of Toxoplasma gondii in raw caprine, ovine, buffalo, bovine, and camel milk using cell cultivation, cat bioassay, capture ELISA. and PCR Methods in Iran. Foodborne Pathog Dis. (2013) 10:120-5. doi: 10.1089/fpd.2012.1311

50. Alvarado-Esquivel C, Romero-Salas D, García-Vázquez Z, Cruz-Romero A, Peniche-Cardeña Á, Ibarra-Priego N, et al. Seroprevalence of Toxoplasma gondii infection in water buffaloes (Bubalus bubalis) in veracruz state, mexico and its association with climatic factors. BMC Vet Res. (2014) 10:232 doi: 10.1186/s12917-014-0232-5

51. Meerburg BG, Kijlstra A. Changing climate-changing pathogens: Toxoplasma gondii in North-Western Europe. Parasitol Res. (2009) 105:17-24. doi: 10.1007/s00436-009-1447-4

52. Albuquerque GR, Munhoz AD, Teixeira M, Flausino W, Medeiros SM, Lopes CWG. Risk factors associated with Toxoplasma gondii infection in dairy cattle, state of rio de janeiro. Pesqui Veterinária Bras. (2011) 31:28790. doi: 10.1590/S0100-736X2011000400003

53. Gautam OP, Chhabra MB, Gupta SL, Mahajan SK. Experimental toxoplasmosis in buffalo calves. Vet Parasitol. (1982) 11:2939. doi: 10.1016/0304-4017(82)90097-8

54. Dubey JP, Hill DE, Jones JL, Hightower AW, Kirkland E, Roberts JM, et al. Prevalence of viable Toxoplasma gondii in beef, chicken, and pork from retail meat stores in the United States: risk assessment to consumers. J Parasitol. (2005) 91:1082-93. doi: 10.1645/GE-683.1

55. Gomes DFC, Krawczak F da S, Oliveira CHS de, Ferreira Júnior Á, Fernandes ÉKK, Lopes WDZ, et al. Toxoplasma gondii in cattle in Brazil: a review. Rev Bras Parasitol Veterinária. (2020) 29:e015719. doi: 10.1590/s1984-29612019106

56. El-Tras WF, Tayel AA, El-Kady NM. Source diversity of Toxoplasma gondii infection during meal preparation. J Food Saf. (2012) 32:15. doi: 10.1111/j.1745-4565.2011.00336.x
57. Gencay YE, Yildiz K, Gokpinar S, Leblebicier A. A potential infection source for humans: Frozen buffalo meat can harbour tissue cysts of Toxoplasma gondii. Food Control. (2013) 30:86-9. doi: 10.1016/j.foodcont.2012. 07.021

58. Dubey JP, Schares G. Neosporosis in animals-The last five years. Vet Parasitol. (2011) 180:90-108. doi: 10.1016/j.vetpar.2011.05.031

59. McAllister MM, Dubey JP, Lindsay DS, Jolley WR, Wills RA, McGuire AM. Dogs are definitive hosts of Neospora caninum. Int J Parasitol. (1998) 28:1473-8. doi: 10.1016/S0020-7519(98)00138-6

60. Dubey JP, Jenkins MC, Rajendran C, Miska K, Ferreira LR, Martins J, et al. Gray wolf (Canis lupus) is a natural definitive host for Neospora caninum. Vet Parasitol. (2011) 181:382-7. doi: 10.1016/j.vetpar.2011.05.018

61. King JS, Šlapeta J, Jenkins DJ, Al-Qassab SE, Ellis JT, Windsor PA. Australian dingoes are definitive hosts of Neospora caninum. Int J Parasitol. (2010) 40:945-50. doi: 10.1016/j.ijpara.2010.01.008

62. Gondim LFP, McAllister MM, Pitt WC, Zemlicka DE. Coyotes (Canis latrans) are definitive hosts of Neospora caninum. Int J Parasitol. (2004) 34:159-61. doi: 10.1016/j.ijpara.2004.01.001

63. de Barros LD, Miura AC, Minutti AF, Vidotto O, Garcia JL. Neospora caninum in birds: a review. Parasitol Int. (2018) 67:397-402. doi: 10.1016/j.parint.2018.03.009

64. Tranas J, Heinzen RA, Weiss LM. Serological evidence of human infection with the protozoan Neospora caninum. Clin Diagn Lab Immunol. (1999) 6:765-67.

65. Williams DJL, Hartley CS, Björkman C, Trees AJ. Endogenous and exogenous transplacental transmission of Neospora caninum - how the route of transmission impacts on epidemiology and control of disease. Parasitology. (2009) 136:1895-900. doi: 10.1017/S0031182009990588

66. de Aquino Diniz LV, Minutti AF, de Souza Lima Nino B, Costa LR, Bosculo MRM, de Almeida BFM, et al. Vertical transmission of Neospora caninum in bovine fetuses from a slaughterhouse in Brazil. Trop Anim Health Prod. (2019) 51:1751-5. doi: 10.1007/s11250-019-01828-y

67. Ferroglio E, Wambwa E, Castiello M, Trisciuoglio A, Prouteau A, Pradere E, et al. Antibodies to Neospora caninum in wild animals from Kenya, East Africa. Vet Parasitol. (2003) 118:43-9. doi: 10.1016/j.vetpar.2003.09.006

68. Campero CM, Pérez A, Moore DP, Crudeli G, Benitez D, Draghi MG, et al. Occurrence of antibodies against Neospora caninum in water buffaloes (Bubalus bubalis) on four ranches in corrientes province, Argentina. Vet Parasitol. (2007) 150:155-8. doi: 10.1016/j.vetpar.2007.09.002

69. Moore DP, Konrad JL, San Martino S, Reichel MP, Cano DB, Méndez S, et al. Neospora caninum serostatus is affected by age and species variables in cohabiting water buffaloes and beef cattle. Vet Parasitol. (2014) 203:25963. doi: 10.1016/j.vetpar.2014.04.011

70. de Oliveira PRF, Soares LBF, Borges J de M, Mota RA, Pinheiro Junior JW. Prevalence and associated factors with Neospora caninum infection in female water buffaloes (Bubalus bubalis) from Pernambuco, Brazil. Rev Bras Parasitol Vet. (2018) 27:439-45. doi: 10.1590/s1984-296120180063

71. Fujii TU, Kasai N, Nishi SM, Dubey JP, Gennari SM. Seroprevalence of Neospora caninum in female water buffaloes (Bubalus bubalis) from the southeastern region of Brazil. Vet Parasitol. (2001) 99:3314. doi: 10.1016/S0304-4017(01)00474-5

72. Gennari SM, Rodrigues AAR, Viana RB, Cardoso EC. Occurrence of anti-Neospora caninum antibodies in water buffaloes (Bubalus bubalis) from the Northern region of Brazil. Vet Parasitol. (2005) 134:16971. doi: 10.1016/j.vetpar.2005.05.064

73. Silva SP, Mota RA, Faria EB, Casseb AR, Casseb LMN, Dias HLT. Comparação das técnicas de ELISA indireto e Imunofluorescência indireta na detecção de anticorpos anti-Neospora caninum em búfalas (Bubalus bubalis). Pesqui Vet Bras. (2013) 33:431-4. doi: 10.1590/S0100-736X2013000400003

74. Vogel FSF, Arenhart S, Bauermann FV. Anticorpos anti-Neospora caninum em bovinos, ovinos e bubalinos no Estado do Rio Grande do sul. Cienc Rural. (2006) 36:1948-51. doi: 10.1590/s0103-84782006000600048

75. Chryssafidis AL, Cantón G, Chianini F, Innes EA, Madureira EH, Soares $\mathrm{RM}$, et al. Abortion and foetal lesions induced by Neospora caninum in experimentally infected water buffalos (Bubalus bubalis). Parasitol Res. (2015) 114:193-9. doi: 10.1007/s00436-014-4178-0 
76. Romero-Salas D, Alvarado-Esquivel C, Domínguez-Aguilar G, CruzRomero A, Ibarra-Priego N, Barrientos-Salcedo C, et al. Seroepidemiology of infection with Neospora caninum, Leptospira, and bovine herpesvirus type 1 in water buffaloes (Bubalus bubalis) in Veracruz, Mexico. Eur J Microbiol Immunol. (2017) 7:278-83. doi: 10.1556/1886.2017.00029

77. Jara V J, Chávez V A, Casas A E, Sánchez P N, Moreno-López J, Merza M. Determinación de anticuerpos contra Neospora caninum en búfalos de agua (Bubalus bubalis) en la Amazonía peruana. Rev Investig Vet del Perú. (2011) 22:61-5. doi: 10.15381/rivep.v22i1.123

78. Valbuena-Carson R, Valeris R, Sánchez E, Ramírez A, Ochoa K, Uzcátegui $\mathrm{D}$, et al. Detección serológica de Neospora caninum (Apicomplexa, Sarcocystidae) en búfalas (Bubalus bubalis) del municipio Colón, estado Zulia, Venezuela. Rev Cient la Fac Ciencias Vet la Univ del Zulia. (2013) 23:396-402.

79. Meenakshi, Sandhu KS, Ball MS, Kumar H, Sharma S, Sidhu PK, et al. Seroprevalence of Neospora caninum antibodies in cattle and water buffaloes in india. J Parasitol. (2007) 93:1374-7. doi: 10.1645/GE-1317.1

80. Sengupta PP, Balumahendiran M, Raghavendra AG, Honnappa TG, Gajendragad MR, Prabhudas K. Prevalence of Neospora caninum antibodies in dairy cattle and water buffaloes and associated abortions in the plateau of Southern Peninsular India. Trop Anim Health Prod. (2012) 45:20510. doi: 10.1007/s11250-012-0192-3

81. Mahajan V, Banga HS, Filia G. Patho-epidemiological and risk factor studies for detection of Neospora-associated abortion in cattle and buffaloes in Punjab, India. Rev Sci Tech l'OIE. (2020) 38:801-8. doi: 10.20506/rst.38.3.3027

82. Hajikolaei MRH, Goraninejad S, Hamidinejat H, Ghorbanpour M, Paryab R. Occurrence of Neospora caninum antibodies in water buffaloes (Bubalus bubalis) from the south-western region of Iran. Bull Vet Inst Pulawy. (2007) 51:233-5.

83. Hamidinejat H, Seifi Abad Shapouri MR, Namavari MM, Shayan P, Kefayat M. Development of an indirect ELISA using different fragments of recombinant Ncgra7 for detection of Neospora caninum infection in cattle and water buffalo. Iran J Parasitol. (2015) 10:69-77.

84. Rezvan H, Khaki A, Namavari M, Abedizadeh R. An investigation of the concurrency of anti-Neospora antibody and parasitemia in water buffalo (Bubalus bubalis) in northwest of Iran. Vet Res forum Int Q J. (2019) 10:79-84. doi: 10.30466/vrf.2019.34314

85. Yagoob G, Yaghuob F, Mohammad HA. Assessment of Neospora caninum seroprevalence in buffalo in Tabriz city, north-west of Iran. Buffalo Bull. (2017) 36:379-84.

86. Mazuz ML, Alvarez-García G, King R, Savisky I, Shkap V, OrtegaMora LM, et al. Exposure to Neospora spp. and Besnoitia spp. in wildlife from Israel. Int J Parasitol Parasites Wildl. (2018) 7:31721. doi: 10.1016/j.ijppaw.2018.08.002

87. Olmo L, Reichel MP, Nampanya S, Khounsy S, Wahl LC, Clark BA, et al. Risk factors for Neospora caninum, bovine viral diarrhoea virus, and Leptospira interrogans serovar hardjo infection in smallholder cattle and buffalo in Lao PDR. PLoS ONE. (2019) 14:e0220335. doi: 10.1371/journal.pone.0220335

88. Olmo L, Dye MT, Reichel MP, Young JR, Nampanya S, Khounsy S, et al. Investigation of infectious reproductive pathogens of large ruminants: are neosporosis, brucellosis, leptospirosis and BVDV of relevance in Lao PDR? Acta Trop. (2018) 177:118-26. doi: 10.1016/j.actatropica.2017.10.007

89. Nasir A, Ashraf M, Khan MS, Yaqub T, Javeed A, Avais M, et al. Seroprevalence of Neospora caninum in dairy buffaloes in Lahore District, Pakistan. J Parasitol. (2011) 97:541-3. doi: 10.1645/GE-2687.1

90. Nasir A, Ashraf M, Shakoor A, Adil M, Abbas T, Kashif M, et al. Co-infection of water buffaloes in Punjab, Pakistan, with Neospora caninum and Brucella abortus. Turkish J Vet Anim Sci. (2014) 38:572-6. doi: 10.3906/vet-1310-36

91. Nasir A, Zaman MA, Shakoor A, Tauseef-Ur-Rehman, Khan I, EhtishamUl- Haque S, et al. Prevalence of Neospora caninum using milk and serum ELISA and its hematological effect in dairy buffaloes. Pak Vet J. (2018) 38:281-5. doi: 10.29261/pakvetj/2018.039

92. Abes NS, Divina BE. Seroprevalence of Neospora caninum in bulgarian murrah buffaloes and its detection in domestic dogs from buffalo dairy herds in Nueva Ecija, Philippines. Philipp J Vet Med. (2008) 45:30-8.
93. Kengradomkij C, Inpankaew $\mathrm{T}$, Kamyingkird $\mathrm{K}$, Wongpanit $\mathrm{K}$, Wongnakphet S, Mitchell TJ, et al. Seroprevalence and risk factors associated with exposure of water buffalo (Bubalus bubalis) to Neospora caninum in northeast Thailand. Vet Parasitol. (2015) 207:156-60. doi: 10.1016/j.vetpar.2014.10.034

94. Nam NH, Chanlun A, Kanistanon K, Aiumlamai S. Seroprevalence of Neospora caninum in swamp buffaloes and beef cattle in the north-east of Thailand. Thai J Vet Med. (2012) 42:213-18.

95. Guarino A, Fusco G, Savini G, Di Francesco G, Cringoli G. Neosporosis in water buffalo (Bubalus bubalis) in southern Italy. Vet Parasitol. (2000) 91:15-21. doi: 10.1016/S0304-4017(00)00239-9

96. Auriemma C, Lucibelli M, Borriello G, Carlo E, Martucciello A, Schiavo L, et al. PCR detection of Neospora caninum in water buffalo foetal tissues. Acta Parasitol. (2014) 59:1-4. doi: 10.2478/s11686-014-0201-y

97. Bărbura? D, Gy?rke A, Ionică AM, Bărbura? R, Mircean V, Cozma V. Evidence of Neospora caninum infection in buffaloes (Bubalus bubalis) from Northwestern Romania. Parasitol Res. (2019) 118:166771. doi: 10.1007/s00436-019-06263-4

98. Neverauskas CE, Nasir A, Reichel MP. Prevalence and distribution of Neospora caninum in water buffalo (Bubalus bubalis) and cattle in the Northern Territory of Australia. Parasitol Int. (2015) 64:3926. doi: 10.1016/j.parint.2015.05.009

99. Romand S, Thulliez P, Dubey JP. Direct agglutination test for serologic diagnosis of Neospora caninum infection. Parasitol Res. (1997) 84:503. doi: $10.1007 / \mathrm{s} 004360050355$

100. Rodrigues AAR, Gennari SM, Aguiar DM, Sreekumar C, Hill DE, Miska KB, et al. Shedding of Neospora caninum oocysts by dogs fed tissues from naturally infected water buffaloes (Bubalus bubalis) from Brazil. Vet Parasitol. (2004) 124:139-150. doi: 10.1016/j.vetpar.2004. 07.007

101. Rodrigues AAR, Gennari SM, Paula VSO, Aguiar DM, Fujii TU, StarkeBuzeti W, et al. Serological responses to Neospora caninum in experimentally and naturally infected water buffaloes (Bubalus bubalis). Vet Parasitol. (2005) 129:21-4. doi: 10.1016/j.vetpar.2004.12.024

102. Chryssafidis AL, Soares RM, Rodrigues AAR, Carvalho NAT, Gennari SM. Evidence of congenital transmission of Neospora caninum in naturally infected water buffalo (Bubalus bubalis) fetus from Brazil. Parasitol Res. (2011) 108:741-3. doi: 10.1007/s00436-010-2214-2

103. Açici M, Bölükbaş CS, Pekmezci GZ, Gürler H, Genç O, Gürler AT, et al. A diagnostic survey of Neospora caninum infection in aborted fetuses in the middle black sea region and sivas province, Turkey. Turkish J Vet Anim Sci. (2019) 43:761-6. doi: 10.3906/vet-1908-16

104. Konrad JL, Moore DP, Crudeli G, Caspe SG, Cano DB, Leunda MR, et al. Experimental inoculation of Neospora caninum in pregnant water buffalo. Vet Parasitol. (2012) 187:72-8. doi: 10.1016/j.vetpar.2011.12.030

105. Chryssafidis AL, Cantón G, Chianini F, Innes EA, Madureira EH, Gennari SM. Pathogenicity of Nc-Bahia and Nc-1 strains of Neospora caninum in experimentally infected cows and buffaloes in early pregnancy. Parasitol Res. (2014) 113:1521-8. doi: 10.1007/s00436-014-3796-X

106. Cantón GJ, Konrad JL, Moore DP, Caspe SG, Palarea-Albaladejo J, Campero $\mathrm{CM}$, et al. Characterization of immune cell infiltration in the placentome of water buffaloes (Bubalus bubalis) infected with Neospora caninum during pregnancy. J Comp Pathol. (2014) 150:463-8. doi: 10.1016/j.jcpa.2013. 12.003

Conflict of Interest: The authors declare that the research was conducted in the absence of any commercial or financial relationships that could be construed as a potential conflict of interest.

Copyright (C) 2020 de Barros, Garcia, Bresciani, Cardim, Storte and Headley. This is an open-access article distributed under the terms of the Creative Commons Attribution License (CC BY). The use, distribution or reproduction in other forums is permitted, provided the original author(s) and the copyright owner(s) are credited and that the original publication in this journal is cited, in accordance with accepted academic practice. No use, distribution or reproduction is permitted which does not comply with these terms. 